Ilmu Pertanian (Agricultural Science)

Vol. 3 No. 2 August, 2018: 66-71

Available online at http://journal.ugm.ac.id/jip

DOI: doi.org/10.22146/ipas.26749

ILMU PERTANIAN

(AGRICULTURAL SCIENCE)

\title{
The Growth and Yield of Shallot (Allium cepa L. Aggregatum group) in Application of Beneficial Microorganisms
}

\author{
Taufiq Hidayat ${ }^{1,2}$, Prapto Yudono ${ }^{1}$, Endang Sulistyaningsih ${ }^{1 *}$, Arif Wibowo ${ }^{3}$ \\ ${ }^{1}$ Department of Agronomy, Faculty of Agriculture, Universitas Gadjah Mada \\ Jln. Flora no. 1, Bulaksumur, Sleman, Yogyakarta 5528, Indonesia \\ ${ }^{2}$ Department of Agrotechnology, Faculty of Agriculture, Universitas Muhammadiyah Yogyakarta \\ JL. Brawijaya, Kasihan, Bantul, Yogyakarta 55183 \\ ${ }^{3}$ Department of Phytopatholoy, Faculty of Agriculture, Universitas Gadjah Mada \\ Jln. Flora no. 1, Bulaksumur, Sleman, Yogyakarta 5528, Indonesia \\ *Corresponding email: endangsih@ugm.ac.id
}

\begin{abstract}
Shallot (Allium cepa L. Aggregatum group) is one of the most widely utilized vegetables in Indonesia. Some technologies have been adapted to improve its productivity, e.g. the application of beneficial microorganisms. Mycorrhizal fungi, Trichoderma sp., and Bacillus thuringiensis as well as the combination of these microorganisms were applied on shallot cultivations. The experiment aims to investigate the effect of those microorganisms on the growth and yield of shallot. The experiment was arranged in a Randomized Complete Block Design with two treatment factors: (1) two shallot cultivars, Biru Lancor and Crok Kuning and (2) six beneficial microorganism treatments, i.e., control, mycorrhizae, Trichoderma sp., Bacillus thuringiensis, mycorrhizae and Trichoderma sp., combination, and those three microorganism combination. The objective was to study the effect of those microorganism application and their combination on the improvement of growth and yield of Crok Kuning and Biru Lancor cultivars. The observation was conducted on infection percentage of mycorrhizae, total population of Trichoderma sp., leaf area, leaf area index, net assimilation rate, crop growth rate, harvest index, and plant yield. The data obtained were subjected to analysis of variance (ANOVA) and continued with Duncan's Multiple Range Test (DMRT) at 5\% significance level. The results showed the leaf area of shallot was improved as affected by the mycorrhizal fungi application. The effectiveness and implication of mycorrhizal fungi on shallot growth would decrease if the application was combined with other microorganisms. However, this application had not been able to increase component yield and yield of Biru Lancor and Crok Kuning.
\end{abstract}

Keywords: Bacillus thuringiensis, microbial interactions, mycorrhizal fungi, Trichoderma sp.

\section{INTRODUCTION}

Shallot (Allium cepa L. Aggregatum group) is one of the most widely utilized Allium by Indonesian people as a spice in dishes and an herbal medicine (Pangestuti \& Sulistyaningsih, 2011). National production of shallot increasing by $5.43 \%$ per year starting from 2004 to 2014 (Direktorat Jenderal Hortikultura, 2016). However, the average of national productivity of shallot was low (10.22 ton ha-1 during 2012-2014) compared to the potential yield of shallot (Direktorat Jenderal Hortikultura, 2016). The productivity value was less than $50 \%$ from the potential yield of some shallots cultivars. Crok Kuning, a local cultivar originated from Bantul Yogyakarta has a potential yield of 24-26 ton ha $^{-1}$ (Anonymous, 2016a), whereas Biru Cultivar a, local cultivar originated from Probolinggo has a potential yield of 12.47-14.08 ton ha $^{-1}$ (Anonymous, 2016b). The low shallot productivity can be improved through genetic modification such as hybrid shallot cultivars (Sulistyaningsih et al., 2002) and agronomy technology such as the application of beneficial microorganism (Akhwan et al., 2012; Darsan et al., 2016; Tuhuteru et al., 2016).

Some beneficial microorganism can enhance the plant productivity through several mechanisms by fixing nitrogen, dissolving phosphate, producing siderophores, secreting phytohormones, and controlling pests and diseases. Nowadays, the most popular beneficial microorganisms used by farmers in shallot 
cultivation are mycorrhizal fungi (Akhwan et al., 2012), Trichoderma sp. (Darsan et al., 2016), and Bacillus thuringiensis.

Mycorrhizal fungi are fungi that form a symbiotic association with the roots of a vascular hostplant (Brundrett, 2004). Previous researchers demonstrated that growth of shallot depends on the presence of mycorrhizal fungi especially in saline soil (Akhwan et al., 2012). Mycorrhizal fungi combine with guano applied at rhizosphere under salinity stress could enhance the root, Net assimilation rate, dry weight of shallot (Akhwan et al., 2012). Mycorrhiza applied at peat soil could enhance plant height, root volume, phosphorus uptake, and bulb dry weight (Suryani et al., 2017). Trichoderma sp. is a filamentous imperfect fungus which is commonly used as a biocontrol for some of the crop diseases and a biofertilizer (Lorito et al., 2010). Application of Trichoderma sp. in shallot bulb at sandy soil could increase plant height, leaf area index, net assimilation rate, crop growth rate, nitrate reductase activities, total chlorophyll and fresh bulb weight (Darsan et al., 2016) and improving seedling of onion (Debire et al., 2016). Bacillus thuringiensis is more often used as a bio-insecticide to eliminate and control pests (Chattopadhyay et al., 2004). Qi et al. (2016) reported that application of Bacillus thuringiensis could enhance shoot dry weight of tomato seed. Wilson et al. (2006) reported that Bacillus thuringiensis were able to produce siderophore.

The applications of mycorrhiza, Trichoderma sp., and Bacillus thuringiensis, as well as the combination among those microorganisms on shallot cultivation, have never reported yet. The objective of this research was to study the effect of the application of mycorrhizal fungi, Trichoderma sp., and Bacillus thuringiensis as well as the combination among those microorganisms on the improvement of growth and yield of Crok Kuning and Biru Lancor cultivars.

\section{MATERIALS AND METHODS}

The field experiment was conducted at Ngantak, Parangtritis, Kretek, Bantul Regency, D.I. Yogyakarta located at S $8^{\circ} 0^{\prime} 23.400^{\prime \prime}$ and E $110^{\circ} 17^{\prime} 52.800^{\prime \prime}$ with the altitude of $9.2 \mathrm{~m}$ above sea level, and flat contour witha slope of $0.5 \%$ from July to September 2015. Geographically, the experimental plot was arranged in Randomized Complete Block Design comprised of two treatment factors, namely shallot cultivars, and type of beneficial microorganisms. The first factor consisted of two cultivars, namely Biru Lancor and Crok Kuning; while the second factor consisted of six microorganism treatments, i.e., control, mycorrhiza, Trichoderma sp., Bacillus thuringiensis, mycorrhiza-Trichoderma sp. combination, and the combination of the three microorganisms. Three blocks were used as replications. All treatments were planted at the same time on a plot size of $2 \mathrm{~m}$ $\mathrm{x} 10 \mathrm{~m}$ with the spacing of $20 \mathrm{~cm} \times 20 \mathrm{~cm}$.

Trichoderma sp. was cultured in Laboratory of Biology, Department of Forestry and Plantation, D.I. Yogyakarta. Mycorrhiza was mixed in a zeolite, and Bacillus thuringiensis were cultivated in Laboratory of Agricultural Microbiology, Universitas Gadjah Mada. Mycorrhiza was applied at dose 2.5 g.plant $^{-1}$ placed under bulb in the planting holes (Sumiati \& Gunawan, 2006). Trichoderma sp.was applied at a dose of $625 \mathrm{~kg} \cdot \mathrm{ha}^{-1}$, was applied within rows when the age of plant was 2 weeks after planting (WAP). Bacillus thuringiensis was sprayed at a dose of 1.5 $\mathrm{mL} . \mathrm{L}^{-1}$ and a volume rate of $175{\mathrm{~L} . h a^{-1}}^{-1}$ wice a week. Fertilizers were used at during planting, 2 WAP and 6 WAP with a total dose of Nitrogen $250 \mathrm{~kg} \cdot \mathrm{ha}^{-1}$, phosphor $220 \mathrm{~kg} \cdot \mathrm{ha}^{-1}$, Potassium $250 \mathrm{~kg} \cdot \mathrm{ha}^{-1}$ and Sulphur $65 \mathrm{~kg} \mathrm{ha}^{-1}$. Organic matters, 2 ton of coconut dusk was applied at the same time of shallot bulbs planting. Spodoptera exigua was controlled using synthetic pesticide with cypermethrin and profenofosas an active ingredient. Stemphylium leaf blight and purple blotch were controlled using synthetic pesticide with carbendazim and azoxystrobin as an active ingredient.

The percentage of mycorrhizal infection was observed at 6 WAP using methods as followed: 25 roots (each $1 \mathrm{~cm}$ length) was rinsed several times with tap water, kept submerged for 24 hours in 10\% $\mathrm{KOH}$ solution, and acidified in $2 \% \mathrm{HCl}$ solution for an hour. After rinsing, the root materials were stained with Acid Fuchsine solution. The stained root specimens were placed in a glass slide and examined by light microscope. Estimation of infection percentage of mycorrhiza was assessed following the method of McGonigle et al. (1990). A total colony of Trichoderma sp. was observed before and after shallot planted. It was observed using methods as follows: $1 \mathrm{~g}$ of composite soil around shallot plant diluted at 3-10, $4-10$, and 5-10 in sterilized water. A volume of 0.1 $\mathrm{ml}$ dilution was placed on Trichoderma Selective Medium (TSM). In TSM for $1 \mathrm{~L}$ contained Calcium Nitrate ( $1 \mathrm{~g})$, Potassium nitrate $(0.26 \mathrm{~g})$, Magnesium sulfate heptahydrate $(0.26 \mathrm{~g})$, Monopotassium phosphate $(0.12 \mathrm{~g})$, Calcium chloride dihydrate $(1 \mathrm{~g})$, Citric acid (0.05 g), Sucrose (2 g), Agar (20 g), Chlortetracycline $(0.05 \mathrm{~g})$ and captan $(0.04 \mathrm{~g})$. 
The data were observed on growth parameters such as leaf area $\left(\mathrm{cm}^{2}\right)$ at 3,6 and 9 weeks after planting (WAP), net assimilation rate $\left(\mathrm{g} .\left(\mathrm{dm}^{2}\right)^{-1}\right.$ .week $\left.{ }^{-1}\right)$, crop growth rate $\left(\mathrm{kg} .\left(\mathrm{m}^{2}\right)^{-1}\right.$. week $\left.\mathrm{k}^{-1}\right)$ at 3-6 WAP and 6-9 WAP, and yield components such as number of bulb per cluster, bulb diameter $(\mathrm{cm})$, bulb weight $(\mathrm{g})$, bulb fresh weight per cluster $(\mathrm{g})$, and harvest index at 9 WAP.

The data obtained were subjected to analysis of variance (ANOVA) and mean comparisons were determined through Duncan's Multiple Range Test (DMRT) at 5\% significance level.

\section{RESULTS AND DISCUSSION}

The key for symbiotic between mycorrhiza and host plant was the infection capability of the mycorrhiza (Smith et al., 2011). It was proven by percentage of mycorrhizal infection on the host plant. The high percentage of mycorrhizal infection on the root indicated the high mycorrhiza development in the plant. Plant with a high percentage of Mycorrhiza infection showed high phosphorus uptake, high root coverage, high shoot development, and high productivity (Smith et al., 2011).

A single application of mycorrhiza would increase the percentage of mycorrhizal infection in the application of mycorrhiza and a total population of Trichoderma sp. in the application of Trichoderma sp., respectively (Table 1). According to Shuab et al. (2014), the inoculation of mycorrhizal fungi on onion would improve the percentage of mycorrhizal infection. Klein \& Eveleigh (1998) categorized Trichoderma sp. into a saprophytic group. The amendment of organic matter at a dose of 2 ton.ha ${ }^{-1}$ on the beginning of the experiment was able to assure the longevity of Trichoderma sp.as shown in a total population of Trichoderma sp., at harvest time (Table 1).

Table 1 presented the decrement of the percentage of mycorrhiza infection when mycorrhiza applied with Trichoderma sp. and/or Bacillus thuringiensis. It was known that Trichoderma sp. was able to produce gliotoxin and viridine as antibiotics and secrete enzyme B-1,3-glucanase, protease, and chitinase that attack the hyphae (resulting in exolytic) (Viterbo et al., 2002). The microorganism-plant competition on nutrition in utilizing root exudate and volatile compounds produced by microorganisms and on growing habitat were the main factors contributing to the decrease of mycorrhizal fungi capability in infecting hostplant (Fracchia et al., 2004).

The application of Mycorrhiza greatly increased the leaf area at 6 WAP (Table 2). According to Deressa and Schenk (2008), the increment of plant growth caused by increment of $\mathrm{P}$ uptake in Onion applied with Mycorrhiza. Phosphor plays a role in cell division, elongation, and enlargement (Karanova et al., 2006). An increment of nutrient uptake was possible through two pathways, which were by root epidermis pathway and by external hyphae of mycorrhizal fungi (Smith et al., 2011). This was in accordance with research done by Bolandnazar et al. (2007) which shown that application of mycorrhiza under three irrigation intervals could increase leaf area index of onion (Allium cepa L. Aggregatum group).

The application of combination between mycorrhiza

Table 1. Percentage of mycorrhizal infection (\%) of Biru Lancor and Crok Kuning at 3 WAP and a total population of Trichoderma sp. $\left(\mathrm{cfu} \mathrm{g}^{-1}\right)$ at the before application and harvest time

\begin{tabular}{|c|c|c|c|}
\hline \multirow{2}{*}{ Treatment } & \multirow{2}{*}{$\begin{array}{c}\text { Percentage of } \\
\text { Mycorrhizal infection }(\%)\end{array}$} & \multicolumn{2}{|c|}{ Total population of Trichoderma sp. (cfu.g ( $^{-1}$ ) } \\
\hline & & Before application & Harvest Time \\
\hline \multicolumn{4}{|l|}{ Cultivar } \\
\hline Biru Lancor & $54.89 \mathrm{p}$ & $4.50 \times 103$ & $3.58 \times 107 p$ \\
\hline Crok Kuning & $56.78 \mathrm{p}$ & $4.50 \times 103$ & $3.56 \times 107 \mathrm{p}$ \\
\hline \multicolumn{4}{|l|}{ Microorganism } \\
\hline Control & $35.66 \mathrm{c}$ & $4.50 \times 103$ & $5.10 \times 104 \mathrm{~b}$ \\
\hline Trichoderma sp. & $34.33 \mathrm{c}$ & $4.50 \times 103$ & $1.79 \times 108 \mathrm{a}$ \\
\hline Mycorrhiza & $89.00 \mathrm{a}$ & $4.50 \times 103$ & $1.68 \times 104 \mathrm{~b}$ \\
\hline Bacillus thuringiensis & $28.66 \mathrm{c}$ & $4.50 \times 103$ & $5.10 \times 103 \mathrm{~b}$ \\
\hline Mycorrhiza-Trichoderma sp. & $75.33 \mathrm{~b}$ & $4.50 \times 103$ & $2.56 \times 107 \mathrm{a}$ \\
\hline Combination of three microorganisms & $72.00 \mathrm{~b}$ & $4.50 \times 103$ & $1.57 \times 107 \mathrm{a}$ \\
\hline $\mathrm{CV}(\%)$ & 15.79 & & $25.76^{*}$ \\
\hline Interaction & $(-)$ & & $(-)$ \\
\hline
\end{tabular}


Table 2. Leaf area $\left(\mathrm{cm}^{2}\right)$ of Biru Lancor and Crok Kuning at 3, 6, and 9 WAP

\begin{tabular}{|c|c|c|c|}
\hline \multirow{2}{*}{ Treatment } & \multicolumn{3}{|c|}{ Leaf Area $\left(\mathrm{cm}^{2}\right)$} \\
\hline & 3 WAP & 6 WAP & 9 WAP \\
\hline \multicolumn{4}{|l|}{ Cultivar } \\
\hline Biru Lancor & $105 \mathrm{q}$ & $423 \mathrm{q}$ & $143 \mathrm{q}$ \\
\hline Crok Kuning & $145 \mathrm{p}$ & $654 \mathrm{p}$ & $196 \mathrm{p}$ \\
\hline \multicolumn{4}{|l|}{ Microorganism } \\
\hline Control & $133 \mathrm{a}$ & $484 \mathrm{~b}$ & $161 \mathrm{a}$ \\
\hline Trichoderma sp. & $126 \mathrm{a}$ & $576 \mathrm{ab}$ & $151 \mathrm{a}$ \\
\hline Mycorrhiza & $96 \mathrm{a}$ & $719 \mathrm{a}$ & $148 \mathrm{a}$ \\
\hline Bacillus thuringiensis & $141 \mathrm{a}$ & $580 \mathrm{ab}$ & $203 \mathrm{a}$ \\
\hline Mycorrhiza-Trichoderma sp. & $108 \mathrm{a}$ & $431 \mathrm{~b}$ & $201 \mathrm{a}$ \\
\hline Combination of three microorganisms & $144 \mathrm{a}$ & $531 \mathrm{~b}$ & $158 \mathrm{a}$ \\
\hline CV $(\%)$ & 26.12 & 24.82 & 30.41 \\
\hline Interaction & $(-)$ & $(-)$ & $(-)$ \\
\hline
\end{tabular}

Note: Mean values in a column followed by same letters indicated no significant difference by DMRT at $\alpha=5 \%$; (-) indicated no interaction between cultivar and microorganism.

and Trichoderma sp. and/or Bacillus thuringiensis decreased the leaf area compared to the single application of mycorrhiza. The decrease of leaf area was closely related to the percentage of mycorrhiza infection that would also be decreased when Mycorrhiza was combined with Trichoderma sp. and/or B. thuringiensis (Table 1). The decrement of the percentage of mycorrhiza infection also affected $\mathrm{P}$ uptake that played role in cell division, elongation, and enlargement (Karanova et al., 2006).

Net assimilation rate in Trichoderma sp. application at week 6-9 week after planting and crop growth rate in mix of three microorganisms at week 6-9 weak after planting had negative value. It is shown that shallot has assimilation rate lower than respiration rate. Net assimilation rate and crop growth rate will decrease during the senescence, where leaf area is decreasing at the same time as a net gain of dry weight.

The individual application of beneficial microorganisms did not give significantly different on a number of bulb per cluster, bulb diameter, bulb weight, bulb fresh weight per cluster, and harvest index (Table 4). In fact, the increased leaf area as affected by mycorrhizal fungi had not been able to

Table 3. Net assimilation rate $\left(\mathrm{g}\left(\mathrm{dm}^{2}\right)^{-1}\right.$ week $\left.^{-1}\right)$ and crop growth rate $\left(\mathrm{kg}_{\left(\mathrm{m}^{2}\right)^{-1} \text { week }}{ }^{-1}\right)$ of Biru Lancor and Crok Kuning at 3-6 WAP and 6-9 WAP

\begin{tabular}{|c|c|c|c|c|}
\hline \multirow[t]{2}{*}{ Treatment } & \multicolumn{2}{|c|}{$\begin{array}{l}\text { Net Assimilation Rate } \\
\left(\mathrm{g} .\left(\mathrm{dm}^{2}\right)^{-1} \text {.week }{ }^{-1}\right)\end{array}$} & \multicolumn{2}{|c|}{$\begin{array}{l}\text { Crop Growth Rate } \\
\left(\mathrm{kg} .\left(\mathrm{m}^{2}\right)^{-1} \cdot \text { week }^{-1}\right)\end{array}$} \\
\hline & 3-6 WAP & 6-9 WAP & 3-6 WAP & 6-9 WAP \\
\hline \multicolumn{5}{|l|}{ Cultivar } \\
\hline Biru Lancor & $0.51 \mathrm{p}$ & $0.070 \mathrm{p}$ & $0.029 \mathrm{q}$ & $-0.0012 p$ \\
\hline Crok Kuning & $0.45 \mathrm{p}$ & $0.110 \mathrm{p}$ & $0.037 \mathrm{p}$ & $0.0080 \mathrm{p}$ \\
\hline \multicolumn{5}{|l|}{ Microorganism } \\
\hline Control & $0.42 \mathrm{a}$ & $0.068 \mathrm{a}$ & $0.028 \mathrm{a}$ & $0.0040 \mathrm{a}$ \\
\hline Trichoderma sp. & $0.57 \mathrm{a}$ & $-0.018 \mathrm{a}$ & $0.041 \mathrm{a}$ & $0.0004 \mathrm{a}$ \\
\hline Mycorrhiza & $0.44 \mathrm{a}$ & $0.105 \mathrm{a}$ & $0.035 \mathrm{a}$ & $0.0043 \mathrm{a}$ \\
\hline Bacillus thuringiensis & $0.47 \mathrm{a}$ & $0.128 \mathrm{a}$ & $0.036 \mathrm{a}$ & $0.0107 \mathrm{a}$ \\
\hline Mycorrhiza-Trichoderma sp. & $0.51 \mathrm{a}$ & $0.245 \mathrm{a}$ & $0.029 \mathrm{a}$ & $0.0136 \mathrm{a}$ \\
\hline Combination of three microorganisms & $0.44 \mathrm{a}$ & $0.036 \mathrm{a}$ & $0.033 \mathrm{a}$ & $-0.0014 \mathrm{a}$ \\
\hline CV (\%) & 22.80 & $28.83^{*}$ & 30.99 & 30.76 \\
\hline Interaction & $(-)$ & $(-)$ & $(-)$ & $(-)$ \\
\hline
\end{tabular}

Note: Mean values in the column followed by same letters indicated no significant difference by DMRT at $\alpha=5 \%$; (-) indicated an no interaction between cultivar and microorganism, *: analysis was performed on root transformation. 
Table 4. Number of bulb per cluster, bulb diameter $(\mathrm{cm})$, bulb weight $(\mathrm{g})$, bulb fresh weight per cluster $(\mathrm{g})$, and harvest index, of Biru Lancor and Crok Kuning

\begin{tabular}{|c|c|c|c|c|c|}
\hline Treatment & $\begin{array}{l}\text { Number of } \\
\text { Bulb } \\
\text { per Cluster }\end{array}$ & $\begin{array}{c}\text { Bulb } \\
\text { Diameter } \\
(\mathrm{cm})\end{array}$ & $\begin{array}{c}\text { Bulb } \\
\text { Weight } \\
\text { (g) }\end{array}$ & $\begin{array}{l}\text { Bulb Fresh } \\
\text { Weight per } \\
\text { Cluster (g) }\end{array}$ & $\begin{array}{l}\text { Harvest } \\
\text { Index }\end{array}$ \\
\hline \multicolumn{6}{|l|}{ Cultivar } \\
\hline Biru Lancor & $7.11 \mathrm{q}$ & $2.08 \mathrm{p}$ & $5.21 \mathrm{p}$ & $26.44 \mathrm{q}$ & $0.566 \mathrm{p}$ \\
\hline Crok Kuning & $9.35 \mathrm{p}$ & $2.05 \mathrm{p}$ & $5.53 \mathrm{p}$ & $43.78 \mathrm{p}$ & $0.582 \mathrm{p}$ \\
\hline \multicolumn{6}{|l|}{ Microorganism } \\
\hline Control & $7.45 \mathrm{a}$ & $2.00 \mathrm{a}$ & $5.05 \mathrm{a}$ & $32.40 \mathrm{a}$ & $0.533 \mathrm{a}$ \\
\hline Trichoderma sp. & $8.78 \mathrm{a}$ & $1.89 \mathrm{a}$ & $4.51 \mathrm{a}$ & $33.83 \mathrm{a}$ & $0.634 \mathrm{a}$ \\
\hline Mycorrhiza & $8.88 \mathrm{a}$ & $2.17 \mathrm{a}$ & $6.40 \mathrm{a}$ & $41.53 \mathrm{a}$ & $0.539 \mathrm{a}$ \\
\hline Bacillus thuringiensis & $8.56 \mathrm{a}$ & $2.18 \mathrm{a}$ & $5.98 \mathrm{a}$ & $41.02 \mathrm{a}$ & $0.633 \mathrm{a}$ \\
\hline Mycorrhiza-Trichoderma sp. & $8.11 \mathrm{a}$ & $1.91 \mathrm{a}$ & $4.88 \mathrm{a}$ & $30.43 \mathrm{a}$ & $0.634 \mathrm{a}$ \\
\hline Combination of three microorganisms & $7.61 \mathrm{a}$ & $2.18 \mathrm{a}$ & $5.13 \mathrm{a}$ & $31.62 \mathrm{a}$ & $0.480 \mathrm{a}$ \\
\hline CV $(\%)$ & $8.78^{*}$ & 12.59 & 21.98 & $19.09 *$ & 18.12 \\
\hline Interaction & $(-)$ & $(-)$ & $(-)$ & $(-)$ & $(-)$ \\
\hline
\end{tabular}

Note: Mean values in the column followed by same letters indicated no significant difference by DMRT at $\alpha=5 \%$; (-) indicated an no interaction between cultivar and microorganism, *: analysis was performed on root transformation.

accelerate net assimilation rate and crop growth rate significantly, so that bulb yield components were not significantly different compared to those of in control. Several factors might contribute to this effect, one of them was the invasion of plant pest organism (PPO). The invasion of PPO might reduce the plant yield up to $100 \%$ yield loss as risky as increase the potency of crop failure (Sakinah, 2013). In the field shallot, was attacked by Spodoptera exigua, Stemphylium leaf blight,and Purple Blotch.

\section{CONCLUSIONS}

The application of mycorrhizal fungi could improve leaf area of shallot and effectiveness and implication of mycorrhizal fungi would decrease if the application was combined with other microorganisms. However, the application of beneficial microorganisms had not been able to increase plant yield of Biru Lancor and Crok Kuning.

\section{REFERENCES}

Akhwan, I.A.S., E. Sulistyaningsih, and J. Widada. 2012. Peran JMA dan Bakteri Penghasil ACC Deaminase terhadap Pertumbuhan dan Hasil Bawang Merah pada Cekaman Salinitas. Vegetalika, (1) 2:139-152.

Anonymous. 2016a. Deskripsi Bawang Merah Varietas Crok Kuning. http:// varitas.net/ dbvarietas/ deskripsi/ 4110.pdf. (Accessed 10 October 2016).

Anonymous. 2016b. Deskripsi Bawang Merah Varietas Biru Lancor. http:// varitas.net/ dbvarietas/ deskripsi/ 2024.pdf. (Accesed 10 October 2016).

Bolandnazar, S., M.R. Neyshabouri, N. Aliasgharzad, and N. Chaperzadeh. 2007. Effect of Mycorrhizal Colonization on Growth Parameter on Onion Under Irrigation and Soil Condition. Pakistan Journal Biological Science, 9:1491-1495

Brundrett, M.C. 2004. Diversity and Classification of Mycorrhizal Associations. Biological Reviews, 78:473-495.

Chattopadhyay A., N.B. Bhatnagar, and R. Bhatnagar. 2004. Bacterial insecticidal toxins. Critical Reviews inMicrobioliogy, 30: 33-54.

Darsan, S., E. Sulistyaningsih, \& A. Wibowo. 2016. Various Shallot Seed Treatments with Trichoderma to Increase Growth and Yield on Sandy Coastal. Ilmu Pertanian, 1(3):94-99.

Debire, T.G., S. Bonzi, I. Somda, and A. Legreve. 2016. Evaluation of The Potential of Trichoderma harzianum as a Plant Growth Promoter and Biological Control Againts Fusarium Damping off in Onion in Burkina Faso. Asian Journal of Plant Pathology, 10: 49-60.

Deressa, T.G. and Schenk, K.M. 2008. Contribution of Roots and Hyphae to Phosphorus Uptake of Mycorrhizal Onion (Allium cepa L.)-A Mechanistic Modeling Approach. Journal Plant Nutrient and Soil Science, 171:810820.

Direktorat Jenderal Hortikultura. 2016. Hasil Pencarian Berdasarkan Indikator: Bawang Merah. https:// aplikasi. pertanian.go.id/ bdsp/h asil_ind.asp. (accessed 10 October 2016).

Fracchia, S., A. Aranda-Rickert, E. Flashland, G. 
Terada, and S. Sede. 2004. Mycorrhizal Compatability and Symbiotic Reproduction of Gavilea australis, an Endangered Terrestrial Orchid from South Patagonia. Mycorrhiza, 28(4): 627-634.

Harman, G. E. 2000. Myths and Dogmas of Biocontrol. Plant Disease, 84:377-393.

Karanova, M., F.A. Lattanzi, A.A. Grimoldi, and H. Schnyder. 2006. Phosphorus Defficiency Decreases Cell Division and Elongation in Grass Leaves. Plant Physiology, 141(2): 766775.

Klein, D. and E. Eveleigh. 1998. Ecology of Trichoderma. In Harman, G.E. and C.P. Kubicek. Trichoderma and Gliocladium Vol. 1 Basic Biology, Taxonomy and Genetics. Taylor and Francis Ltd. London. $278 \mathrm{p}$.

Lorito M, Woo LS, Harman GE, and Monte E. 2010. Translational research on Trichoderma: from omics to the field. Annual Review of Phytopathology, 48:395-417.

McGonigle, T.P., M.H. Miller, D.G. Evans, G.L. Fairchild, and J.A. Swan. 1990. A New Method Which Gives an Objective Measure of Colonisation of Roots by Vesicular-Arbuscular Mycorrhizal Fungi. A New Pathologist, 115(3) 495-501.

Pangestuti, R. and E. Sulistyaningsih. 2011. Potensi Penggunaan True Seed Shallot (TSS). Sebagai Sumber Benih Bawang Merah di Indonesia. Prosiding Smiloka Nasional: Dukungan Agro-Inovasi untuk Pemberdayaan Petani Kerjasama UNDIP, BPTP Jateng, dan Pemrov Hateng. 258-266.

Qi, J., D. Aiuchi, M. Tani, S. Asano, and M. Koike. 2016. Potential of Entomopathogenic Bacillus thuringiensis as Plant Growth Promoting Rhiobacteria and Biologicl Control Agents for Tomato Fusarium Wilt. International Journal of Environmental and Agriculture Research, 2(6):55-63.

Sakinah, F. 2013. Analisis Pengaruh Faktor Cuaca Untuk Prediksi Serangan Organisme Pengganggu Tanaman (OPT) pada Tanaman Bawang Merah. (skripsi) Bogor: Institut Pertanian Bogor.

Shuab, R., R. Lone, J. Naidu, V. Sharma, S. Imtiyaz, and K.K. Koul. 2014. Benefits of Inoculation of Arbuscular Mycorrhizal Fungi on Growth and Development of Onion (Allium cepa) Plant. American-Eurasian Journal of Agriculture \& Environmental Science, 14 (6): 527-535.

Smith, S.E., I. Jakobsen, M. Gronlund, and F.A. Smith. 2011. Roles of Arbuscular Mycorrhizas in Plant Phosphorus Nutrition: Interaction Between Pathways of Phosphorus Uptake in Arbuscular Mycorrhizal Roots Have Important Implication for Understanding and Manipulating Plant Phosphorus Acquisition. Plant Physiology, 156:1050-1057.

Sulistyaningsih, E., K. Yamashita and Y. Tashiro. 2002. Haploid Induction from F1 Hybrid between CMS Shallot with Allium galanthum Cytoplasm and Common Onion by Unpollinated Flower Culture. Euphytica, 125:139-144.

Sumiati, E. and O.S. Gunawan. 2006. Aplikasi pupuk hayati Mikoriza untuk meningkatkan efisiensi serapan unsur hara NPK serta pengaruhnya terhadap hasil dan kualitas umbi bawang merah. Jurnal Hortikultura, 17(1):3442.

Suryani, R., S. Gafur and T. Abdurrahman. 2017. Respon Tanaman Bawang Merah Terhadap Cendawan Mikoriza Arbuskula (CMA) pada Cekaman Kekeringan di Tanah Gambut. Jurnal Pedon Tropika, 1(3):69-78.

Tuhuteru, S., E. Sulistyaningsih, and A. Wibowo. 2016. Effects on Plant Growth Promoting Rhizobacteria (PGPR) on Growth and Yield of Shallot in Sandy Coastal Land. Ilmu Pertanian, 1(3):105-110.

Viterbo A, U. Landau, S. Kim, L. Chernin, and I. Chet.2010. Characterization of ACC deaminase from the biocontrol and plant growth-promoting agent Trichoderma asperellum T203. FEMS Microbiology Lettets, 305:42-8.

Wilson M.K., R.J. Abergel, K.N. Raymond, J.E.L. Arceneaux, and B.R. Byers. 2006. Siderophores of Bacillus anthracis, Bacillus cereus and Bacillus thuringiensis. Biochemical and Biophysical Research Communications, 348: 320-325. 